Falah: Jurnal Ekonomi Syariah

(p)ISSN: 2502-3918; (e)ISSN: 2502-7825

Vol 4, No 2 (Agustus 2019), pp.172-182

DOI: https://doi.org/10.22219/jes.v4i2.9874

\title{
Pembentukan Citra Merek Minimarket Melalui Viral Marketing (Studi Kasus Minimarket 212)
}

\author{
Yulia Hamdaini Putri, Dessy Yunita \& Aslamia Rosa \\ Program Studi Manajemen, Universitas Sriwijaya \\ Email: yuliahamdaini@unsri.ac.id
}

\begin{abstract}
Brand image is one of the important aspects of marketing, this also happens to the 212 minimarket which is being discussed lately. The aims of this study is to understand the role of viral marketing on the formation of brand images and interest in shopping at minimarket 212 . This study is qualitative using questi0nonaire as the method of data collection. The population of this research is the general population of Palembang aged 16-69 years who have sufficient knowledge about 212 minimarkets. The result of this study, are as follows: first, that viral marketing has a significant effect on brand image (Est: 0.426; SE: 0.033; CR: 0.033; P: 000). Second, that viral marketing has a significant effect on behavioral intentions (Est: 0.261; SE: 0.040; CR: 6.538; P: 0.000). Third, that brand Image has a significant effect on behavioral intentions (Est: 1,187; SE: 0,067; CR: 17,708; P: 0,000). Thus, the effect of viral marketing on shopping interest in a 212 minimarket has the smallest influence value among other variables which is only 0.26 point. However, with the brand image variable as an intervening variable, the effect is greater up to 0.50 point, this means that brand image which formed through viral marketing get a good response from the public to increase the willingness to shop.
\end{abstract}

Keywords: viral marketing, brand image, behavioral intention. 


\begin{abstract}
ABSTRAK
Citra merek adalah salah satu aspek penting dari pemasaran, hal ini juga terjadi pada 212 minimarket yang sedang dibahas akhir-akhir ini. Tujuan dari penelitian ini adalah untuk memahami peran pemasaran viral pada pembentukan citra merek dan minat berbelanja di minimarket 212. Penelitian ini adalah kuantitatif dengan menggunakan kuesioner sebagai metode pengumpulan data. Populasi penelitian ini adalah populasi umum Palembang usia 16-69 tahun yang memiliki pengetahuan cukup tentang 212 minimarket. Hasil penelitian ini, adalah sebagai berikut: pertama, bahwa pemasaran viral memiliki pengaruh signifikan terhadap citra merek (Est: 0,426; SE: 0,033; CR: 0,033; P: 000). Kedua, bahwa pemasaran viral memiliki pengaruh signifikan terhadap niat perilaku (Est: 0,261; SE: 0,040; CR: 6.538; P: 0.000). Ketiga, citra merek itu memiliki pengaruh signifikan terhadap niat perilaku (Est: 1,187; SE: 0,067; CR: 17,708; P: 0,000). Dengan demikian, pengaruh pemasaran viral terhadap minat belanja di 212 minimarket memiliki nilai pengaruh terkecil di antara variabel lain yang hanya 0,26 poin. Namun, dengan variabel citra merek sebagai variabel intervening, pengaruhnya lebih besar hingga 0,50 poin, ini berarti citra merek yang terbentuk melalui pemasaran viral mendapat respons yang baik dari masyarakat untuk meningkatkan kemauan berbelanja.
\end{abstract}

Kata Kunci: Pemasaran Viral, Citra Merek, Niat Perilaku.

\title{
1. Pendahuluan
}

Sektor ritel berdasarkan grafik leisure yang dikeluarkan oleh Bank Indonesia menunjukkan adanya pertumbuhan sebesar 0,3 persen, dari 4,58 tumbuh persen menjadi 4,87 persen. Ritel dengan segmen food and beverage saat ini masih diminati (www.properti.kompas.com, 2018). Seiring pertumbuhan penduduk dan kenaikan pendapatan masyarakat, industri ritel mampu hadir di daerah pemukiman penduduk dari pusat kota, daerah pinggiran sampai ke pelosok desa.

Berdasarkan laporan Bappenas dalam Proyeksi Penduduk Indonesia 20102035, jumlah penduduk Indonesia pada 2020 bakal mencapai 271 juta jiwa atau bertambah 10 juta dari jumlah penduduk pada tahun lalu. Pada 2035, jumlah penduduk Indonesia akan menembus 300 juta. (www.databoks.katadata.com, 2018). Untuk Pertumbuhan ekonomi, tercatat BPS Tahun 2017 pertumbuhan 
ekonomi Indonesia sebesar 5,07\%. Lebih baik dibandingkan pencapaian tahun sebelumnya sebesar 5,02\% (www.cnbc.indonesia.com, 2018).

Industri ritel terdiri dari berbagai macam jenis., yaitu hypermarket, supermarket, department store, convenience store dan minimarket. Hypermarket merupakan skala ritel paling besar, supermarket dan department store berskala sedang dan sedangkan convenience store dan minimarket merupakan skala kecil. Berdasarkan penelitian terdahulu tidak terdapat perbedaan pengaruh bauran pemasaran terhadap kepuasan konsumen antara convenience store dan minimarket (Hamdaini, Yulia, 2011).

Minimarket saat ini di Indonesia dalam kegiatan usahanya dibagi dua macam. Kegiatan usaha tersebut terdiri dari waralaba dan konvensional. Dalam kegiatan waralaba ada royalti yang harus dibayarkan kepada pewaralaba, standar barang dan kondisi tempat yang harus sama, dan beberapa kebijakan yang harus ditaati. Keuntungan dari sistem waralaba ini, orang tidak perlu sulit berpikir tentang manajemennya karena sudah ada. Berbeda dengan konvensional, sistem ini dalam kegiatan usahanya dijalankan berdasarkan pembagian laba (jika usaha ini patungan) dan tidak memiliki kebijakan waralaba. (Dabija \& Raluca, 2014)

Berasal dari aksi bela Islam pertama, kedua dan ketiga menimbulkan ide untuk mendirikan koperasi syariha 212 di Sentul Bogor Jawa Barat, tepatnya Januari 2017. Koperasi syariah ini selanjutnya berbentuk minimarket yang diberi merek 212. Minimarket tersebut saat ini berjumlah 33 gerai, sedangkan di Palembang terdapat lima gerai ( http://koperasisyariah212.co.id/212mart/, 2018).

Dalam pemasarannya baik menarik konsumen atau pun investor, minimarket 212 mengandalkan sosial media dan web. Pesan dilakukan secara berantai melalui whats app, line, facebook dan twitter yang selanjutnya lebih dikenal electronic word of mouth. Mudahnya pemasaran ini juga didukung oleh peristiwa 212 yang pernah terjadi sehingga merek 212 ini lebih mudah diingat masyarakat. 212 juga memberikan kesan citra minimarket ini sebagai kegiatan usaha yang berbasis syariah sehingga cocok untuk masyarakat yang mayoritasnya muslim. Hal ini didukung penelitian sebelumnya menyebutkan bahwa nilai keutamaan dan minat berpengaruh terhadap koperasi syariah di Palembang (Hamdaini \& Syathiri, 2016).

Electronic word of mouth memiliki kaitan dengan viral marketing. Viral marketing merupakan strategi pemasaran berbasis teknologi yang dalam penyampaiannya komunikasi melalui pesan jejaring sosial, pesan yang disampaikan tersebut dapat lebih cepat melekat dibenak konsumen. Sesuai dengan penelitian terdahulu viral marketing memiliki pengaruh positif dan signifikan terhadap kesadaran merek. (Sulistyo \& Subagio, 2015). Namun, apakah viral marketing juga dapat membangun merek pada perusahaan ritel, untuk itu perlu diteliti lebih lanjut. 


\section{Tinjauan Pustaka}

\subsection{Pengertian Pemasaran}

Menurut Kotler dan Armstrong (2008: 6): The process by which companies create value for customers and build strong customer relationships in order to capture value from customers in return. Yang dapat diartikan sebagai berikut "Pemasaran (marketing) sebagai proses dimana perusahaan menciptakan nilai bagi pelanggan dan membangun hubungan yang kuat dengan pelanggan, dengan tujuan menangkap nilai dari pelanggan sebagai imbalannya."

Sedangkan menurut Alma (2007:12): "Pemasaran adalah kegiatan atau usaha para pengusaha yang menyalurkan barang dan jasa dari titik produsen ke titik konsumen."

Dari berbagai definisi mengenai pemasaran di atas, pada dasarnya mempunyai tujuan dan persepsi yang sama dan dapat disimpulkan bahwa pemasaran merupakan suatu rangkaian aktifitas atau kegiatan dimana individu atau suatu kelompok dapat membuat gagasan atau ide yang bernilai, proses komunikasi, dan menyampaikan nilai, melalui proses pertukaran barang dan jasa yang bernilai dan membangun hubungan dengan pihak lain yang kuat untuk kepentingan organisasi dan stakeholder dengan tujuan untuk dapat mengidentifikasi, mengantisipasi, dan memenuhi kebutuhan sosial dan keinginan manusia.

\subsection{Viral Marketing}

Viral marketing, juga dikenal sebagai word-of-mouth (WOM) atau "buzz marketing", adalah taktik menciptakan sebuah proses di mana orang-orang yang tertarik dapat saling memasarkan satu sama lain (Subramahi \& Rajagopalan, 2003). Menurut J. Kim et al, tidak semua virality metrics efektif dalam meningkatkan penerimaan pesan umpan balik. Viral marketing atau pemasaran viral (menular seperti virus) adalah bentuk lain dari mulut ke mulut, atau "berita dari satu klik mouse ke klik berikutnya (word of mouth)", yang mendorong konsumen menceritakan produk dan jasa yang dikembangkan perusahaan atau informasi audio, video, dan tertulis kepada orang lain secara online (Kotler dan Keller, 2008: 256). Secara teoritis dan empiris, seharusnya tidak mengherankan bahwa pemasar online yang ingin menerapkan kampanye "kirim-ke-teman" dan "pemasaran viral" menghadapi tantangan yang besar. Namun Bruyn et al (2008) menemukan bahwa walaupun hubungan dekat dapat efektif dalam menangkap perhatian penerima dan menciptakan kesadaran (mis., Untuk mengarahkan lalu lintas ke tempat awalan), mereka tidak memiliki pengaruh pada tahap selanjutnya.

\subsection{Brand Image (Citra Merek)}

Membangun citra suatu industri ritel yang sesuai dengan kegiatan usaha secara keseluruhan sangat penting. Citra industri ritel mencerminkan siapa pelanggan yang dilayaninya. Peritel dapat membangun citra tertentu di mata masyarakat seperti, ekonomis, mewah, inovatif semuanya harus sesuai dengan unsur 
pelayanan. Adapun dimensi dari citra merek adalah sebagai berikut (Sääksjärvi, et al 2011):

1) Kredibilitas merek adalah perusahaan mampu memberikan apa yang telah dijanjikan dan keunggulan yang mereka siarkan

2) Karakter merek adalah beberapa kesan yang dimiliki dari suatu merek. Seperti 1) Mencerminkan manfaat dan kualitas 2)Singkat dan sederhana 3) Mudah dibaca didengar, diucapkan, dibaca dan diingat. 4) Memilki kesan yang berbedadari merek-merek yang sudah ada 5) Mudah diterjemahakan kedalam bahasa asing dan tidak mengandung konotasi negatif dalam bahasa asing. 6) Dapat didaftarkan dan mendapat perlindungan hukum sebagai hak paten.

3) Keseluruhan sikap terhadap merek, sikap menaruh kepercayaan terhadap merek, evaluasi emosional (kesenangan atau sebaliknya), kecenderungan adanya tindak lanjut terhadap merek (melakukan pembelian)

4) Perasaan merek yaitu tanggapan dan reaksi pelanggan yang secara emosi terhadap merek yang digunakan, diantaranya adalah perasaan positif dan kehangatan, pengakuan sosial

Ajzen dalam Lisa et al (2016) mengemukakan bahwa niat perilaku ditentukan dengan sikap terhadap perilaku, norma subjektif, dan kontrol yang dirasakan. Faktor-faktor, termasuk informasi produk, harga produk, keterlibatan produk, dan kata dari mulut ke mulut, memiliki dampak positif pada niat beli, sementara kualitas produk tidak berpengaruh efektif terhadap kemauan membeli. (Lee et al, 2017).

\subsection{Hubungan antara Viral marketing, Brand image dan Minat Belanja}

Metrik viralitas merujuk ke statistik deskriptif yang dihasilkan komputer yang ditampilkan di situs web untuk mewakili interaksi pengguna gabungan dengan konten yang tersedia secara online (Walther \& Jang, 2012 dalam penelitian Kim). Hasil penelitian Kim (2018) indikator share berpengaruh signifikan terhadap peningkatan minat beli. Selanjutnya, viral marketing, celebrity endorser dan brand image berpengaruh positif dan signifikan terhadap keputusan pembelian secara bersama-sama (Kristanto, Indraningrat, \& Prasetiyaningtiyas, 2017). Implikasi dari penelitian Kennedy, Kapitan, \& Soo tahun 2016 untuk pengecer tidak hanya menganggap merek dan posisi mereka, namun juga menunjukkan pentingnya orientasi ritel yang otentik - yang memiliki keberlanjutan pada intinya. Citra merek secara signifikan mempengaruhi e-WOM dan komitmen, menunjukkan bahwa SMMA memiliki efek positif pada merek (Seo \& Park, 2018). Tidak seperti iklan tradisional, pesan melalui viral marketing mungkin dapat dipercaya karena motivasi komunikator bersifat pro-sosial (untuk mendidik atau membantu) daripada proaktif (untuk mendapatkan pelanggan baru) sebagai pendorong minat 
belanja (Phelps, Lewis, Mobilio, \& Perry, 2004). Selanjutnya, penggunaan media sosial sebagai platform pesan, inti dari bagaimana pasar ditargetkan dan produk dikirimkan (Kohli, Suri, \& Kapoor, 2014). Adapun perbedaan penelitian ini dengan penelitian-penelitian terdahulu adalah kedudukan brand image sebagai variabel moderating dalam minat belanja konsumen pada ritel (minimarket).

\section{Metode Penelitian}

Populasi penelitian ini adalah masyarakat umum kota Palembang yang berusia 16-69 Tahun yang memiliki pengetahuan cukup tentang minimarket 212. Jumlah masyarakat kota Palembang berdasarkan https://palembangkota.bps.go.id/ data ter- update tahun 2015 berjumlah 1.121.233. Untuk menarik sampel dari populasi, dalam penelitian ini digunakan penarikan sampel dengan perhitungan tabel Krejcie dan Morgan dengan alpha (sampling error) sebesar 5\%. Dengan demikian, jumlah sampel yang dibutuhkan adalah 384 responden. Jumlah responden 384 orang juga mempertimbangkan telah mencukupi batas minimum untuk dilakukan analisis SEM dalam pengambilan sampelnya adalah Non Probability sampling yaitu setiap anggota populasi tidak memiliki peluang yang sama untuk terpilih menjadi sampel. Pemilihan sampel menggunakan Purposive Sampling yaitu dipilih sesuai dengan kebutuhan penelitian.

Pengumpulan data dengan angket (Questinonaire) yaitu sejumlah pertanyaan secara tertulis yang berusaha untuk dijawab oleh responden, agar peneliti memperoleh data lapangan/empiris untuk memecahkan masalah penelitian. Skala Likert digunakan sebagai ukuran kuantitatif untuk penilaian pernyataan persetujuan dari responden. Angket pada penelitian ini dirancang dengan menggunakan skala interval model Likert.

Tabel 1.1.

Variabel Penelitian

\begin{tabular}{|c|c|c|}
\hline Variabel & Sub Variabel & Pengukuran \\
\hline $\begin{array}{c}\text { Viral } \\
\text { marketing }\end{array}$ & $\begin{array}{ll}\text { - } & \text { Informasi audio } \\
\text { - } & \text { Informasi video } \\
\text { - } & \text { Informasi media } \\
& \text { sosial }\end{array}$ & Ordinal \\
\hline Citra Merek & $\begin{array}{ll}\text { - } & \text { Kredibilitas } \\
& \text { merek } \\
\text { - } & \text { Karakter merek } \\
\text { - } & \text { Sikap terhadap } \\
& \text { merek } \\
\text { - } & \text { Perasaan Merek }\end{array}$ & Ordinal \\
\hline Minat Belanja & - $\quad$ Kunjungi Niat & Ordinal \\
\hline
\end{tabular}

Falah: Jurnal Ekonomi Syariah 


\begin{tabular}{|l|l|l|}
\hline & Niat untuk \\
& Menyebarkan \\
& Word-of-Mouth \\
$\bullet$ & Kesediaan untuk \\
& Bayar \\
& Kesediaan \\
& Membayar \\
& Premium \\
(membayar & \\
lebih) & \\
\hline
\end{tabular}

Sumber: diolah dari berbagai sumber (2018)

\section{Analisis dan Pembahasan}

Dalam persaingan usaha, perusahaan berlomba-lomba menempatkan diri dalam benak konsumen, mereka membentuk dan membangun merek untuk menguatkan posisi. Di Indonesia dapat kita bagi dua pembentukan merek yaitu berbasis syariah dan konvensional. Minimarket 212 ini memposisikan diri sebagai minimarket berbasis syariah, yang mana dalam system investasinya perusahaan ini terbentuk dari koperasi syariah 212. Pemerekan secara islami mengartikan bahwa suatu perusahaan atau bisnis eceran tersebut dalam menjalankan operasional bisnisnya berdasarkan prinsip syariah dan mengutamakan penawaran produk produk memiliki logo halal (Yusof, L, Jusoh, \& J, 2014)

Mayoritas pengunjung minimarket 212 adalah masyarakat beragama Islam (61\%) dengan rentang usia 15 tahun sampai dengan 69 tahun, dengan frekuensi sering, jarang dan sesekali saja. 49\% masyarakat beragama Islam memiliki pengetahuan tentang minimarket tersebut melalui media social namun belum pernah berkunjung dengan berbagai alasan, di antaranya kurangnya informasi mengenai keberadaaan minimarket 212 di wilayah perumahan mereka. Mereka yang tergabung dalam organisasi keislaman lebih sering berbelanja di minimiarket 212, hubungan antara konsumen mungkin lebih kuat dan dianggap sama atau lebih dapat dipercaya daripada hubungan 'tradisional' antara konsumen individual dan informasi yang digambarkan dalam strategi pemasaran atau hubungan masyarakat oleh perusahaan itu sendiri (Nicholas, Kamakshi, \& Iyer, 2015).

Media social yang digunakan oleh responden adalah Instagram, Whatsapp, Path, Twitter, Path, Line, Facebook, dan Telegram. Untuk pengguna Instagram, 89, 9 persen menggunakan aplikasi ini, 39 responden atau 10, 1 persen tidak menggunakan. Selanjutnya Whatsapp, 350 responden menggunakan aplikasi ini atau 90, 7 persen, sisanya 9, 3 persen tidak menggunakan aplikasi ini. Lain hal dengan Twitter, 127 responden atau 32, 9 persen penggunaan twitter sisanya 252 responden atau 67, 1 persen tidak menggunakan. Path mirip penggunaannya dengan aplikasi instagram. Saat ini jumlah penggunanya hanya 70 responden atau 18,1 persen penggunaan path sisanya 316 responden atau 81,9 persen tidak 
menggunakan. Pengguna Line berjumlah 306 responden atau 79,3 persen sisanya 80 responden atau 20,7 persen tidak menggunakan. Selanjutnya Facebook 230 responden atau 59,6 persen sisanya 156 responden atau 40,4 persen tidak menggunakan. Terakhir, Telegram 29 responden atau 7,9 persen sisanya 357 responden atau 92,5 persen tidak menggunakan. Kesimpulannya adalah dalam penggunaan media social urutan terbanyak diukur dari jumlah responden adalah Whats app (90, 7 persen) dan terbanyak kedua adalah Instagram (89,9 persen). Selanjutnya yang paling sedikit penggunanya adalah Telegram (7,9 persen). Dalam electronic word of mouth ini lingkungan jejaring pertemanan media social masih berada dalam lingkungan keluarga, saudara, kerabat dan pertemanan, sehingga penyampaian informasi dan ajakan berbelanja di minimarket 212 dipengaruhi oleh mereka. Hal ini sesuai dengan Yeoh, E., Othman, K., \& Ahmad, H. (2013).

Pada pengujian, Model Pengukuran Goddness of fit untuk mengukur kesesuaian model antara variable viral marketing, brand image (citra merek) dan minat belanja secara keseluruhan baik (GFI=0,923, TLI=0,955, CFI=0,971, Parcimony Ratio=0,643). Dengan demikian model penelitian ini dapat digunakan.

Dari ketiga variable yang diuji semua memiliki pengaruh, baik Viral marketing terhadap brand image (Est=0,43, $\mathrm{SE}=0,33, \mathrm{CR}=13,016, \mathrm{P}=0,000)$ maupun brand image bertindak sebagai variable intervening terhadap minat belanja $(\mathrm{Est}=0,50)$. Brand image sendiri memiliki pengaruh signifikan terhadap minat belanja (Est=1,187, SE=0,67, CR 17,788 $\mathrm{P}=0,000$ ). Pengaruh viral marketing terhadap minat belanja pada minimarket secara langsung memiliki nilai pengaruh paling kecil di antara hubungan pengaruh variabel lainnya yaitu hanya sebesar 0,26. Namun, dengan adanya variabel brand image sebagai variabel intervening maka pengaruhnya lebih besar yaitu sebesar 0,50 hal ini berarti brand image dibentuk melalui viral marketing sehingga mendapat tanggapan dari masyarakat yang meningkatkan minat untuk berbelanja. Hal ini sesuai dengan penelitian-penelitian terdahulu (Kristanto, dkk. 2017; Seo \& Park, 2018; Phelps, dkk, 2004). Kedepannya viral marketing dapat digunakan sebagai strategi pemasaran tidak hanya untuk tempat berbelanja online, tempat pariwisata, rumah sakit tetapi juga perusahaan retail seperti minimarket. Pada penelitian selanjutnya diharapkan sampel lebih focus berasal dari organisasi keislaman.

\section{Kesimpulan}

Berdasarkan hasil analisis dan pembahasan dapat diambil kesimpulan sebagai berikut: pertama, viral marketing berpengaruh signifikan terhadap brand image (Est: 0,426; SE: 0,033; CR: 0,033; P: 000). Kedua, Viral marketing berpengaruh signifikan terhadap minat belanja (Est: 0,261; SE: 0,040; CR: 6,538; P:0,000). Ketiga, Brand Image berpengaruh signifikan terhadap minat belanja (Est: 1,187; SE: 0,067; CR: 17,708; P: 0,000). Selain itu, memanfaatkan media social untuk melakukan penawaran promo terhadap produk-produk kebutuhan rumah tangga. 
Kedua, membangun citra merek melalui kekuatan pesan berantai media social. Ketiga, meningkatkan jumlah pengunjung dengan mengetahui minat belanja dan penambahan layanan jasa lainnya seperti yang kompetitor lakukan. Saran untuk akademisi: untuk penelitian lebih lanjut difokuskan pada perbandingan strategi pemasaran pada jenis perusahaan ritel yang berbeda. 


\section{Daftar Pustaka}

Latan, Hengky (2013). Model Persamaan Struktural: Teori dan Implementasi Amos 21. Bandung: Alfabeta.

Santoso, Singgih. Konsep Dasar dan Aplikasi SEM dengan Amos 22. Jakarta : PT Elex Media Computindo.

Subramani, Mani R. and Rajagopalan, Balaji, (2003), Knowledge-sharing and influence in online social networks via viral Marketing, Communications of the ACM, Volume 46, Number 12, 300-307.

Adelsarbanlar, N., \& Khoshtinat, B. (2016). Critical factors and advantage factors influencing the implementation of viral marketing by considering the mediating role of Islamic marketing; a conceptual approach. Procedia Economics and Finance, 36(16), 433-440. http://doi.org/10.1016/S22125671(16) 30061-2

Bruyn, A. De, \& Lilien, G. L. (2008). A multi-stage model of word-of-mouth influence through viral marketing. intern.J.of Research in Marketing, 151163(2008), 151-163. http://doi.org/10.1016/j.ijresmar.2008.03.004

Dabija, D., \& Raluca, B. (2014). Empirical Study on the Impact of Service , Communication and Corporate Social Responsability on the Image of Romanian Retail Brands, 109, 906-912. http://doi.org/10.1016/j.sbspro.2013.12.563

Hamdaini, Y., \& Syathiri, A. (2016). PENGARUH PERSEPSI DAN MINAT TERHADAP KEBERADAAN BAITUL MAL WATTAMWIL (BMT) DI KOTA PALEMBANG.

Kennedy, A., Kapitan, S., \& Soo, S. (2016). Eco-warriors: Shifting sustainable retail strategy via authenic retail brand image. Australasian Marketing Journal (AMJ), 1-10. http://doi.org/10.1016/j.ausmj.2016.03.001

Kim, J. W. (2018). They Liked and Shared: Effects of Social Media Virality Metrics on Perceptions of Message Influence and Behavioral Intentions. Computers in Human Behavior. http://doi.org/10.1016/j.chb.2018.01.030

Kohli, C., Suri, R., \& Kapoor, A. (2014). Will social media kill branding? Business Horizons. http://doi.org/10.1016/j.bushor.2014.08.004

Kotler, Philip dan Kevin Lane Keller, 2008. Manajemen Pemasaran, Jilid 1, Penerbit Erlangga. Jakarta

Kristanto, O. D., Indraningrat, K., \& Prasetiyaningtiyas, S. (2017). PENGARUH VIRAL MARKETING , CELEBRITY ENDORSER DAN BRAND IMAGE TERHADAP KEPUTUSAN PEMBELIAN DI DISTRO RMBL. Bisma Jurnal Bisnis Dan Manajemen, 11(1), 62-75.

Lee, W., Cheng, S., \& Shih, Y. (2017). Asia Paci fi c Management Review Effects among product attributes, involvement, word-of-mouth, and purchase intention in online shopping. Asia Pacific Management Review, 22(4), 223-229. http://doi.org/10.1016/j.apmrv.2017.07.007

Lisa, Y., Mattila, A. S., \& Lee, S. (2016). A meta-analysis of behavioral intentions for environment-friendly initiatives in hospitality research. International Journal of Hospitality Management, 54, 107-115. http://doi.org/10.1016/j.ijhm.2016.01.010

Nicholas, K., Kamakshi, M., \& Iyer, S. (2015). Online Behaviour of Social Media Participants ' and Perception of Trust, Comparing Social Media Brand 
Community Groups and Associated Organized Marketing Strategies, 177(July 2014), 432-439. http://doi.org/10.1016/j.sbspro.2015.02.389

Phelps, J. E., Lewis, R., Mobilio, L., \& Perry, D. (2004). Viral Marketing or Electronic Word-of-Mouth Advertising: Examining Consumer Responses and Motivations to Pass Along Email. Journal of Advertising Research, 44(4).

Sääksjärvi, M., \& Samiee, S. (2011). Relationships among Brand Identity , Brand Image and Brand Preference: Differences between Cyber and Extension

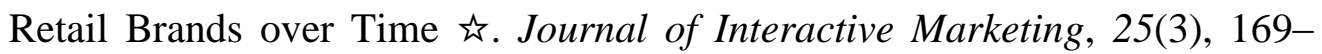
177. http://doi.org/10.1016/j.intmar.2011.04.002

Seo, E., \& Park, J. (2018). A study on the e ff ects of social media marketing activities on brand equity and customer response in the airline industry. Journal of Air Transport Management, 66(September 2017), 36-41. http://doi.org/10.1016/j.jairtraman.2017.09.014

Yeoh, E., Othman, K., \& Ahmad, H. (2013). Understanding medical tourists : Word-of-mouth and viral marketing as potent marketing tools. Tourism Management, 34, 196-201. http://doi.org/10.1016/j.tourman.2012.04.010

Yusof, M., L, Y., Jusoh, W., \& J, W. (2014). Islamic Branding: The Understanding and Perception. Procedia-Social and Behavioral Sciences, 130, 179-185. http://doi.org/10.1016/j.sbspro.2014.04.022 